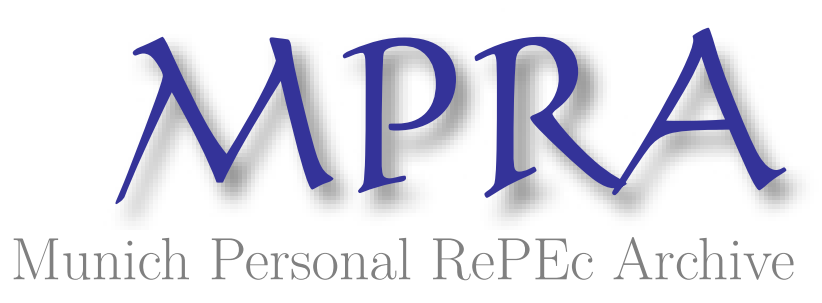

\title{
Welfare implications of country size in a monetary union
}

\author{
Mykhaylova, Olena \\ University of Richmond, VA
}

31 August 2009

Online at https://mpra.ub.uni-muenchen.de/23323/

MPRA Paper No. 23323, posted 16 Jun 2010 00:11 UTC 


\title{
Welfare Implications of Country Size In a Monetary Union
}

\author{
Olena Mykhaylova* \\ University of Richmond, VA
}

June 15, 2010

\begin{abstract}
This paper calculates differences in welfare costs of nominal rigidities in large and small EMU countries. I use a two-country DSGE model characterized by optimizing agents, monopolistic wage and price setting, distortionary taxes and government debt dynamics. I find that these costs are virtually identical for all members of the EMU, and small countries are not at a disadvantage when it comes to the setting of the common monetary policy. This conclusion is primarily due to highly correlated technological processes in Europe, which cause national and Euro-wide inflations to move together. These findings are robust to the asset market structure, trade openness, and different specifications of the Taylor rule.
\end{abstract}

Key words: European monetary union, nominal rigidities, welfare costs JEL classification: E31, E58, E63, F33.

\section{Introduction}

The question of whether or not the creation of the Economic and Monetary Union (EMU) in Europe was a good idea is far from settled. Now that ten years have passed since the inception of the Euro, and various indicators of Europe's economic activity became available, the attention of many economists has been focused on analyzing the workings of the EMU. The global financial crisis of 2008 has forced the economic community to reexamine the costs and benefits of having a single monetary policy in a group of European counties. Do all members of the EMU receive adequate attention from the European Central Bank (ECB), or does the monetary policy favor large countries over small? In the latter case, could alternative fiscal arrangements be used to better stabilize individual countries in the presence of various shocks? Going even further, how would the answers change if small countries retained their monetary independence?

*Department of Economics, 1 Gateway Road, University of Richmond, VA, 23173. Tel: (804) 289-8598; fax: (804) 289-8878. Email: omykhayl@richmond.edu 
In this paper, I address these questions within the framework of New Neoclassical Synthesis, which is characterized by the presence of nominal inertia and therefore lends itself easily to analyzing the interaction of monetary and fiscal policies. In particular, I use a two-country general equilibrium model of a currency union to study the relationship between country size and its costs of wage and price rigidities. To the best of my knowledge, very few authors have done research in this area. Canzoneri et al (2004) use a two-country partialequilibrium model calibrated to the EMU to find that the central bank pays less attention to small countries' inflations. The authors calculate that small EMU countries incur up to four times higher welfare costs of price and wage rigidities (around 1.9 percent of consumption) than their large neighbors.

Recent papers that study the EMU in a general equilibrium setup do so either using a symmetric currency union model, or link country sizes directly to the size of the home bias in consumer demand function ${ }^{1}$. Thus, consumers in a small country demand a (proportionately) small amount of domestic goods and a large amount of goods produced abroad. This assumption carries with it two important implications.

First, as can be seen in Figure 1, while smaller countries do tend to be more open, their share of trade in GDP is by no means connected to their relative size in the union, which makes it difficult to justify small home biases in smaller countries.

Second, equating home bias and country size means that both members of the currency union have the same composition of their consumption baskets (e.g., 10 percent of the small country good) and therefore pay the same price for them. The two CPIs equalize and move in lockstep unless a preference shock perturbs the home biases themselves. This of course minimizes inflation differentials (and therefore welfare costs of having the common monetary authority) in the two countries.

The main contribution of this paper lies in separating country size from home bias to better understand the impact of various shocks on national inflations and on monetary policy responses in a currency union. In addition, I augment the standard New-Keynesian two-country DSGE model with a more realistic economic structure by allowing for incomplete international asset markets, distortionary taxes, labor market rigidities, and non-zero steady state government debt. Within this framework I pose the following two questions: (1) are the welfare costs of nominal rigidities in the EMU related to country size, and (2) which feature(s) of the model have the biggest influence on the differences in these costs across countries. Most recent studies only address one of these issues; EMU papers generally have a positive focus, while welfare literature concentrates on the United States.

The finding of this study is that the welfare costs of nominal inertia are very similar for the EMU countries regardless of their relative size. Productivity correlations and intra-union trade act as price-correcting mechanisms following

\footnotetext{
${ }^{1}$ See, for example, Benigno (2004), Duarte and Wolman (2003), and Ferrero (2005), among many others.
} 


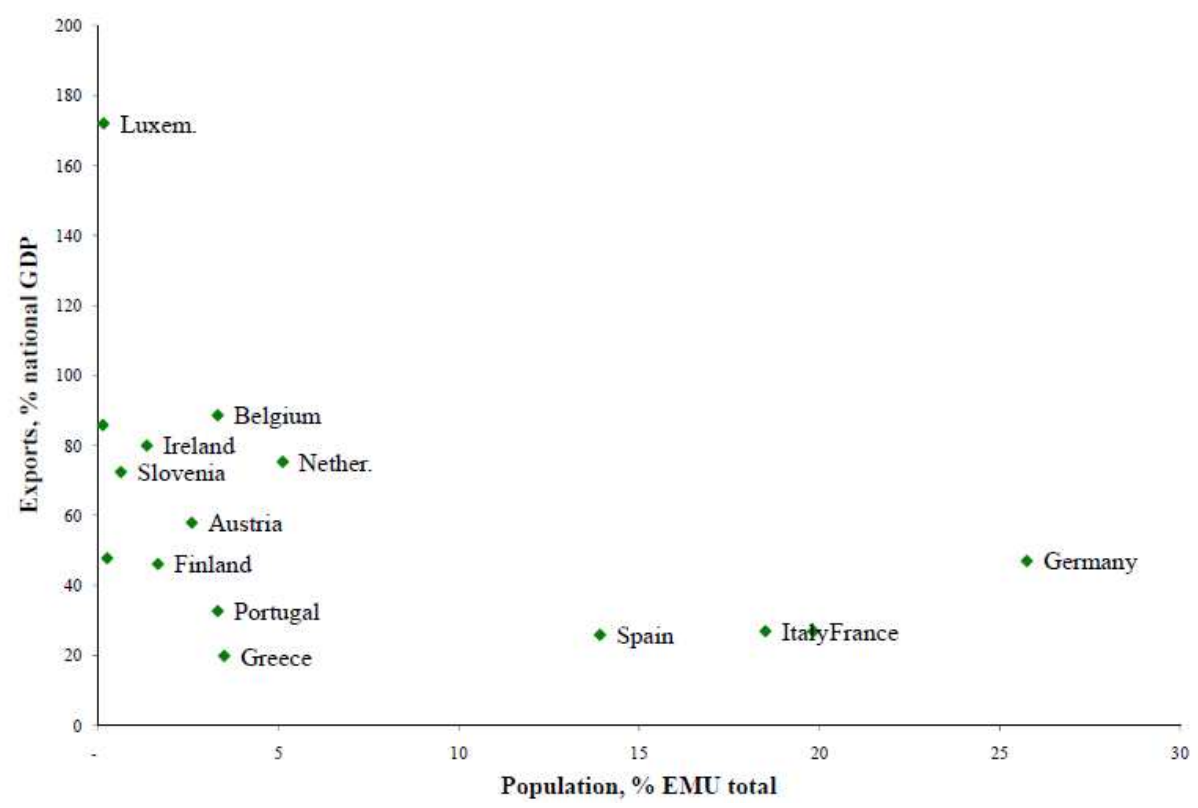

Figure 1: Export Shares in the EMU, 2007. Scatter plot of import shares looks almost identical to this graph. Source: Eurostat.

country-specific shocks and so help to stabilize the monetary union by reducing national inflation differentials and lowering the costs of idiosyncratic disturbances. Intuitively, sticky wages and prices slow down the response of marginal costs to productivity shocks; at the same time, positive correlation of the latter ensures that when marginal costs begin adjusting, they move in the same direction. Since inflation is given by discounted expectations of future marginal costs, the response of the central bank to the original disturbance turns out to be appropriate for both countries. This result is robust to different specifications of international asset markets, monetary policy rule (including the introduction of independent monetary policy in each country), trade openness, and several key parameter values.

In should be noted at the outset that New Keynesian models underestimate the importance of demand shocks in explaining variability of inflation (I will further discuss this issue below). Admittedly, some of the results may be driven by this problem; therefore, this study should be viewed as the first step in analyzing the relationship between country size and its welfare.

The rest of the paper is structured as follows: the theoretical model is presented in section 2; section 3 discusses calibration; section 4 presents simulations results; robustness checks are discussed in section 5 ; finally, section 6 concludes. 


\section{The Model}

The currency union is composed of two countries, home $(H)$ and foreign $(F)$. Both countries are populated by infinitely lived households of measure $M$ in the home country and $M^{*}$ in the foreign; there is no migration. Households consume all varieties of home and foreign goods and have access to international markets where they can trade a state-contingent nominal bond (this assumption will be relaxed later). Each country has a measure one of firms that use labor and capital to produce a continuum of domestic goods, which are then traded internationally. Firms are monopolistically competitive, and the prices they set for their products are sticky. Labor and capital are assumed to be countryspecific, and capital investment is subject to adjustment costs.

I model each country as having only the traded goods sector. Empirical studies provide mixed evidence on the relative importance of traded and non-traded goods sectors in generating the observed cross-country inflation differentials ${ }^{2}$. Therefore, for modeling simplicity, I assume that all goods are traded.

\section{$2.1 \quad$ Firms}

Each country has a continuum of firms indexed by $f$ on the unit interval. At time $t$, each home firm rents capital $K_{t-1}(f)$ from the domestic households at the rate $R_{t}$, hires a labor bundle $N_{t}(f)$ at the rate $W_{t}$ and produces one of the varieties of the domestic good. Each firm is free to set its own price level $P_{H, t}(f)\left(P_{F, t}(f)\right.$ in the foreign country). The Law of One Price holds, so every product sells from the same price at home and abroad.

As a matter of notation, subscripts $H$ and $F$ will refer to a good's country of origin; asterisks will indicate that it is consumed in country $F$. For example, $C_{H}^{*}$ denotes consumption of country $H$ 's good in country $F$. The two economies have a similar structure; therefore, most of the equations will be presented only for the home country.

Home firms use the following CRS technology to produce output:

$$
Y_{H, t}(f)=Z_{t} K_{t-1}(f)^{\nu} N_{t}(f)^{1-\nu},
$$

where $0<\nu<1$, and $Z_{t}$ denotes the level of productivity enjoyed by all the home firms at time $t$. Productivity in the two countries evolves according to the following autoregressive process:

$$
\left[\begin{array}{c}
Z_{t} \\
Z_{t}^{*}
\end{array}\right]=\left[\begin{array}{ll}
A_{11} & A_{12} \\
A_{21} & A_{22}
\end{array}\right]\left[\begin{array}{c}
Z_{t-1} \\
Z_{t-1}^{*}
\end{array}\right]+\left[\begin{array}{c}
\varepsilon_{z, t} \\
\varepsilon_{z, t}^{*}
\end{array}\right]
$$

and $\varepsilon$ 's aren't serially correlated. I abstract from long-term trends in productivity processes, since the focus of this work is on business cycle fluctuations.

\footnotetext{
${ }^{2}$ Altissimo et al (2005) present evidence that inflation dispersion in the EMU stems primarily from the non-traded goods sectors; on the other hand, Andrés et al (2006) find that there is a lower but still persistent inflation dispersion in the industrial goods (excluding energy).
} 
All goods varieties are then bundled into a composite home and foreign goods using the Dixit-Stiglitz aggregator:

$$
Y_{H, t}=\left[\int_{0}^{1} Y_{H, t}(f)^{\frac{\sigma-1}{\sigma}} d f\right]^{\frac{\sigma}{\sigma-1}}, \quad Y_{F, t}=\left[\int_{0}^{1} Y_{F, t}(f)^{\frac{\sigma-1}{\sigma}} d f\right]^{\frac{\sigma}{\sigma-1}}
$$

with $\sigma>1$. These composite goods can then be used for public and private consumption or private investment; the corresponding demand for firm $f$ 's product depends on its price relative to the average $^{3}$ :

$$
Y_{H, t}^{d}(f)=\left[\frac{P_{H, t}(f)}{P_{H, t}}\right]^{-\sigma} Y_{H, t} \quad Y_{F, t}^{d}(f)=\left[\frac{P_{F, t}(f)}{P_{F, t}}\right]^{-\sigma} Y_{F, t}
$$

As in Calvo (1983), home and foreign firms reset their prices each period with a constant probability $(1-\alpha)$ and $\left(1-\alpha^{*}\right)$, respectively; otherwise, the old prices remain in effect. If a (home) firm $f$ gets to announce a new price in period $t$, it chooses $\tilde{P}_{H, t}(f)$ to maximize its expected future profits

$$
E_{t} \sum_{j=t}^{\infty} \Omega_{t, j} \alpha^{j-t}\left[\tilde{P}_{H, t}(f) Y_{H, j}^{d}(f)-T C_{H, j}\left(Y_{H, j}^{d}(f)\right)\right]
$$

$\Omega_{t, j}$ is the home households' stochastic discount factor: $\Omega_{t, j}=\beta^{j-t}\left(\frac{\lambda_{j}}{\lambda_{t}}\right)$, where $\lambda_{t}$ is the marginal utility of nominal wealth (defined in the next subsection). The optimal price and marginal costs are given by

$$
\begin{aligned}
\tilde{P}_{H, t} & =\frac{\sigma}{\sigma-1} \frac{E_{t} \sum_{j=t}^{\infty}(\alpha \beta)^{j-t} \lambda_{j} P_{H, j}^{\sigma} Y_{H, j} M C_{j}}{E_{t} \sum_{j=t}^{\infty}(\alpha \beta)^{j-t} \lambda_{j} P_{H, j}^{\sigma} Y_{H, j}} \\
M C_{t} & =\frac{R_{t}^{\nu} W_{t}^{1-\nu}}{Z_{t} \nu^{\nu}(1-\nu)^{1-\nu}}
\end{aligned}
$$

Given the price-setting behavior of individual firms, the aggregate price level in the country can be written as

$$
P_{H, t}^{1-\sigma}=(1-\alpha) \tilde{P}_{H, t}^{1-\sigma}+\alpha P_{H, t-1}^{1-\sigma}
$$

\subsection{Households}

There is a continuum of households in the home country, indexed by $i$ on the interval $[0, M]$. A representative household maximizes expected lifetime utility

$$
U_{t}(h)=E_{t} \sum_{j=t}^{\infty} \beta^{j-t}\left\{\frac{C_{j}(h)^{1-\Theta}}{1-\Theta}-(1+\chi)^{-1} L_{j}(h)^{1+\chi}\right\}
$$

\footnotetext{
${ }^{3}$ Imposing the zero-profit condition, the prices (in the common currency) of the bundles are given by $P_{H, t}=\left[\int_{0}^{1} P_{H, t}(f)^{1-\sigma} d f\right]^{\frac{1}{1-\sigma}}$ and $P_{F, t}=\left[\int_{0}^{1} P_{F, t}(f)^{1-\sigma} d f\right]^{\frac{1}{1-\sigma}}$.
} 
Here $C_{t}(h)$ denotes the household's consumption of the composite good, which is aggregated from home and foreign goods using the CES aggregator:

$$
C_{t}(h)=\left[\mu_{t}^{\frac{1}{\eta}} C_{H, t}(h)^{\frac{\eta-1}{\eta}}+\left(1-\mu_{t}\right)^{\frac{1}{\eta}} C_{F, t}(h)^{\frac{\eta-1}{\eta}}\right]^{\frac{\eta}{\eta-1}}
$$

$\eta$ is the elasticity of substitution between home and foreign goods, and $0<$ $\mu_{t}<1$ determines the degree of home bias. The time subscript on $\mu$ is needed to model demand (preference) shocks. $C_{t}^{*}(h)$ denotes consumption of the aggregate good (with a different home bias $\mu_{t}^{*}$ ) in the foreign country.

The prices of the two final goods, which also represent the countries' CPIs, are given by

$$
\begin{aligned}
P_{t} & =\left[\mu_{t} P_{H, t}^{1-\eta}+\left(1-\mu_{t}\right) P_{F, t}^{1-\eta}\right]^{\frac{1}{1-\eta}} \\
P_{t}^{*} & =\left[\mu_{t}^{*} P_{F, t}^{1-\eta}+\left(1-\mu_{t}^{*}\right) P_{H, t}^{1-\eta}\right]^{\frac{1}{1-\eta}}
\end{aligned}
$$

Given these prices, the household $(h)$ demands the following quantities of the composite goods:

$$
C_{H, t}^{d}(h)=\mu_{t}\left[\frac{P_{H, t}}{P_{t}}\right]^{-\eta} C_{t}(h), \quad C_{F, t}^{d}(h)=\left(1-\mu_{t}\right)\left[\frac{P_{F, t}}{P_{t}}\right]^{-\eta} C_{t}(h)
$$

Households supply differentiated labor services to all the firms in their country ${ }^{4}$. Each household enjoys a degree of monopolistic power in setting its wage $W_{t}(h)$. The demand for household $(h)$ 's labor services can be written as ${ }^{5}$

$$
L_{t}^{d}(h)=\left[\frac{W_{t}(h)}{W_{t}}\right]^{-\phi} \frac{N_{t}}{M}
$$

Each household faces the following budget constraint:

$$
\begin{gathered}
E_{t}\left[\Delta_{t, t+1} D_{t+1}(h)\right]+B_{t+1}^{d}(h)+P_{t}\left(1+\tau_{c, t}\right) C_{t}(h)+P_{I, t} I_{t}(h)+P_{t} T_{t}(h)= \\
=\left(1-\tau_{w, t}\right) W_{t}(h) L_{t}^{d}(h)+D_{t}(h)+\left(1+i_{t-1}\right) B_{t}^{d}(h)+ \\
+\left(1-\tau_{k, t}\right) R_{t} K_{t-1}(h)+\tau_{k, t} \delta P_{I, t} K_{t-1}(h)+\Pi_{t}(h)
\end{gathered}
$$

The first term on the left-hand side is the price of a portfolio of statecontingent bonds traded internationally, and $D_{t}$ is the payoff of such portfolio in period $t . B_{t}^{d}(h)$ represents household's demand for the riskless one-period

\footnotetext{
${ }^{4}$ The composite labor bundle used in production by any given home firm is given by $N_{t}(f)=M^{\frac{1}{1-\phi}}\left[\int_{0}^{M} L_{t}(h, f)^{\frac{\phi-1}{\phi}} d h\right]^{\frac{\phi}{\phi-1}}$. The scaling factor $M^{\frac{1}{1-\phi}}$ is necessary to maintain the aggregate relationship $N_{t}=\int_{0}^{1} N_{t}(f) d f=M L_{t}(h)$. Together with the expression $K_{t}=$ $M K_{t}(h)$ this will ensure that the production function exhibits constant returns to scale. Additionally, in the steady state the aggregate wage $W$ will equal the individual wage $W(h)$.

${ }^{5}$ Similar to the price of the bundle of goods, the expressions for aggregate wage is $W_{t}=$ $M^{\frac{1}{\phi-1}}\left[\int_{0}^{M} W_{t}(h)^{1-\phi} d h\right]^{\frac{1}{1-\phi}}$.
} 
nominal domestic government bond ${ }^{6}$. Households receive transfers $P_{t} T_{t}(h)$ from their government. $\tau_{c, t}, \tau_{w, t}$ and $\tau_{k, t}$ are taxes on consumption, labor income and capital income, respectively; effectively, households pay tax on nominal capital income and get an inflation-adjusted rebate on depreciated capital. $\Pi_{t}(h)$ represent household's dividend income, and $I_{t}(h)$ denotes investment.

The household's capital accumulation is given by

$$
K_{t}(h)=(1-\delta) K_{t-1}(h)+I_{t}(h)-\frac{1}{2} \psi\left[\frac{I_{t}(h)}{K_{t-1}(h)}-\delta\right]^{2} K_{t-1}(h)
$$

The investment good $I_{t}(h)$ is aggregated from home and foreign bundles just as in (5), but I allow for a different investment home bias ${ }^{7}$.

Households maximize utility (4) subject to the budget constraint (9), labor demand (8) and capital accumulation constraint (10) by choosing wage rate $W_{t}(h)$, consumption $C_{t}(h)$, portfolio holdings $D_{t+1}(h)$ and $B_{t+1}^{d}(h)$, and investment $I_{t}(h)$.

Wages are sticky, and in any given period a household gets to reset its wage with probability $(1-\omega)\left(\left(1-\omega^{*}\right)\right.$ abroad $)$. The optimal new wage satisfies

$$
\left[\tilde{W}_{t}\right]^{\phi \chi+1}=\frac{\phi}{\phi-1} \frac{E_{t} \sum_{j=t}^{\infty}(\omega \beta)^{j-t}\left\{W_{j}^{\phi(\chi+1)}\left(\frac{N_{j}}{M}\right)^{1+\chi}\right\}}{E_{t} \sum_{j=t}^{\infty}(\omega \beta)^{j-t}\left\{\lambda_{j}\left(1-\tau_{w, j}\right) W_{j}^{\phi} \frac{N_{j}}{M}\right\}}
$$

Similar to the derivations of the aggregate price level given firms' first-order conditions, the aggregate wage level is given by

$$
W_{t}^{1-\phi}=(1-\omega) \tilde{W}_{t}^{1-\phi}+\omega W_{t-1}^{1-\phi}
$$

The rest of the first order conditions are fairly standard. International risksharing conditions and households' first order conditions imply that

$$
q_{t}=\Gamma \frac{C_{t}^{\Theta}(h)\left(1+\tau_{c, t}\right)}{C_{t}^{* \Theta}(h)\left(1+\tau_{c, t}^{*}\right)},
$$

where $q_{t} \equiv \frac{P_{t}^{*}}{P_{t}}$ is the relative CPI index (price of foreign consumption bundle in terms of home consumption bundle, not equal to one due to the presence of the home bias in the two countries) and constant $\Gamma$ is determined by the initial consumption conditions at home and abroad ${ }^{8}$.

\footnotetext{
${ }^{6}$ In the presence of the complete set of Arrow securities $D_{t}$, government bonds are redundant for the purposes of risk-sharing; I introduce them to model the dynamics of national debt.

${ }^{7} I_{H, t}(h)$ (and later $G_{H, t}$ ) has the same composition with respect to the differentiated intermediate home goods as $Y_{H, t}$ in (1). Similarly, $I_{F, t}(h)$ and $G_{F, t}$ have the same composition with respect to intermediate foreign goods as $Y_{F, t}$ in (1). Notice, however, that the degree of home bias in investment $\left(\vartheta_{t}\right)$ may be different from consumption home bias $\left(\mu_{t}\right)$ and government home bias $\left(\zeta_{t}\right)$; the latter is defined below. Consequently, the price of investment $P_{I, t}$ may be different from the price of consumption $P_{t}$.

${ }^{8}$ While the existence of the internationally traded bond simplifies aggregation by equalizing
} 


\subsection{The Government}

The instrument of the common monetary authority is the short-term nominal interest rate $i_{t}$. The conduct of monetary policy has important implications for national fiscal governments because the value of the interest rate affects interest payments on national debt. In addition, price and wage stickiness offer a channel for monetary policy to affect real activity in both economies.

The monetary authority sets the interest rate in response to the aggregate monetary union inflation $\pi_{t}$ :

$$
\begin{aligned}
i_{t} & =\left(1-\rho_{i}\right) \bar{i}+\rho_{i} i_{t-1}+\varpi\left(1-\rho_{i}\right) \pi_{t}+\varepsilon_{i, t} \\
\pi_{t} & =\kappa \pi_{H, t}+\kappa^{*} \pi_{F, t}
\end{aligned}
$$

Here $\bar{i}=-\log (\beta)$ is the steady state level of the interest rate. $\kappa \equiv \frac{M}{M+M^{*}}$ and $\kappa^{*} \equiv \frac{M^{*}}{M+M^{*}}$ measure the relative size of the two regions, and $\varpi$ indicates the relative weight on inflation targeting ${ }^{9}$.

I chose to exclude the output gap from the Taylor rule for several reasons. First, "The primary objective of the ECB's monetary policy is to maintain price stability. The ECB aims at inflation rates of below, but close to, $2 \%$ over the medium term."10 Moreover, the existing empirical literature does not seem to agree on the value of the coefficient on the gap term: estimates (based on monthly data) range from statistically insignificant to $1.03{ }^{11}$. Finally, the focus of this paper is on the differences of welfare costs among countries of different size, rather than on the costs themselves (the latter clearly would be strongly influenced by the value of the gap term coefficient), or on the choice of optimal monetary policy. I perform a robustness check (results available upon request) by adding the output gap term to the monetary policy rule, and the main conclusion of the paper does not change: nominal costs of inertia are almost identical in small and large members of the monetary union.

The home country fiscal authority has the following budget constraint (expressed in per capita terms):

$$
\begin{gathered}
B_{t+1}^{s}+\tau_{c, t} P_{t} C_{t}+\tau_{w, t} W_{t} N_{t}+\tau_{k, t} K_{t-1}\left(R_{t}-\delta P_{I, t}\right)= \\
=\left(1+i_{t-1}\right) B_{t}^{s}+P_{G, t} G_{t} / M+P_{t} T_{t}
\end{gathered}
$$

Here $G_{t}$ denotes aggregate government purchases, which may have a different home bias (and therefore a different price) than the consumption or investment

marginal utilities of wealth in the two countries, it has an uncomfortable implication that the variation in the relative consumption growth rates is directly linked to the volatility of the inflation dispersion. To see this, divide (11) by its lag to get $\frac{C_{t}}{C_{t-1}} \frac{C_{t-1}^{*}}{C_{t}^{*}}=\left[\frac{P_{t}^{*}}{P_{t-1}^{*}} \frac{P_{t-1}}{P_{t}}\right]^{-\Theta}=$ $\left[\frac{\pi_{F, t}}{\pi_{H, t}}\right]^{-\Theta}$. In the data, the correlation between these two variables is rather low [see, for example, Chari et al (2002)].

${ }^{9}$ This specification of the monetary policy is the model-consistent representation of the actual ECB weighted measure of aggregate inflation.

${ }^{10}$ http://www.ecb.int/mopo/html/index.en.html

${ }^{11}$ A non-exhaustive list of such studies includes Andrés, López-Salido and Vallés (2006), Hayo and Hofman (forthcoming), Gerlach-Kristen (2003), and Gerdesmeier and Roffia (2004). 
goods. Analogous equations (with starred variables) describe the fiscal policy in the foreign country.

Each government has five tools at its disposal to affect the functioning of its domestic economy: three taxes, transfers, and purchases. In this model, government purchases are described by an autoregressive process as follows:

$$
\log G_{t}=\left(1-\rho_{g}\right) \log \bar{G}+\rho_{g} \log G_{t-1}+\varepsilon_{g, t}
$$

Taxes are assumed to be constant ${ }^{12}$; transfers react to the debt-to-GDP ratio to ensure long-run fiscal solvency:

$$
\log T_{t}=\left(1-\rho_{t r}\right) \log \bar{T}+\rho_{t r} \log T_{t-1}+\rho_{b}\left(\log \bar{B}-\log B_{t-1}\right)
$$

In the above equations, bars denote steady state variables; shocks to government variables are uncorrelated white noise processes.

\subsection{Aggregation and Equilibrium}

Since the measure of households in the two countries is not one, aggregate and per-capita quantities will be different in equilibrium: aggregate consumption is a multiple of the per-capita value: $C_{t}=M C_{t}(h)$. Similar expressions link aggregate and per-capita investment and capital.

Given the above expressions for the aggregate price and wage levels, the aggregate output can be rewritten in terms of aggregate capital stock $K_{t-1} \equiv$ $\int_{0}^{1} K_{t-1}(f) d f$ and the economy-wide labor input $N_{t} \equiv \int_{0}^{1} N_{t}(f) d f$ :

$$
\begin{aligned}
Y_{H, t} & =Z_{t} K_{t-1}^{\nu} N_{t}^{1-\nu} D P_{t}^{-1} \\
D P_{t} & =\int_{0}^{1}\left[\frac{P_{H, t}(f)}{P_{H, t}}\right]^{-\sigma} d f=(1-\alpha)\left[\frac{P_{H, t}}{\widetilde{P}_{H, t}}\right]^{\sigma}+\alpha\left[\frac{P_{H, t}}{P_{H, t-1}}\right]^{\sigma} D P_{t-1},
\end{aligned}
$$

where the last term is a measure of the aggregate price dispersion in the economy.

Equilibrium in the economy is defined by the market clearing conditions and the first order conditions of the agents, given the form of monetary and fiscal policy rules described above.

\subsection{Incomplete Asset Markets}

The assumption of complete markets is not innocuous in that it tightly links volatility of consumption to inflation fluctuations and through these to the interest rate movements (see equation (11)). Such high correlations are not observed in the data. Additionally, if households do not have access to contingent securities markets, their welfare losses from market frictions may be higher. For these

\footnotetext{
${ }^{12}$ The presence of non-zero distortionary taxes helps to bring the dynamics of the model closer to the empirical data and to compare welfare results with existing literature. The simulations presented below have been replicated with all tax rates set to zero, which did not change the qualitative results of this paper.
} 
reasons, I reproduce the welfare calculations in the incomplete asset markets setting.

The modeling of incomplete markets is borrowed from Benigno (2001) and Andrés et al (2006). Households can allocate their wealth between domestically traded state-contingent claims $\left(D_{t}\right.$ in the home country, $D_{t}^{*}$ in the foreign country) and domestic government bonds, denoted by $B_{t}^{d}$ in the home country and $B_{t}^{* d}$ abroad.

Additionally, all households can buy an internationally traded one period risk-free bond $A_{t}$ with the gross nominal rate of return $1+i_{t}$. However, home and foreign consumers pay different prices for this bond: foreign households pay the usual price $\left(1+i_{t}\right)^{-1}$, while home consumers' price $\left[1+i_{t}-p\left(e^{a_{t}}-1\right)\right]^{-1}$ depends on their position in the international asset market. Here $a_{t} \equiv \frac{A_{t}}{P_{t} C_{t}}$ is the ratio of the aggregate asset holdings by home consumers to their consumption, and the parameter $p$ captures transaction $\operatorname{costs}^{13}$. As lenders, domestic households pay a higher price for the bond, and as borrowers they must offer a rate of return higher than $\left(1+i_{t}\right)$. Thus, markets are complete within each country, but consumers cannot perfectly share risk internationally.

This specification breaks down the consumption-inflation relationship in (11). Now, following a shock that reduces real income in the home country, home consumers must borrow in the international markets to maintain their consumption level; however, the increasing cost of borrowing will drive a wedge between home and foreign marginal utilities of consumption and thus potentially increase the costs of nominal inertia in small countries.

More specifically, the representative home consumer's budget constraint becomes

$$
\begin{gathered}
E_{t}\left[\Delta_{t, t+1} D_{t+1}(h)\right]+B_{t+1}^{d}(h)+A_{t+1}(h)+P_{t}\left(1+\tau_{c, t}\right) C_{t}(h)+P_{I, t} I_{t}(h)+P_{t} T_{t}(h)= \\
=\left(1-\tau_{w, t}\right) W_{t}(h) L_{t}^{d}(h)+D_{t}(h)+\left(1+i_{t-1}\right) B_{t}^{d}(h)+\left[1+i_{t-1}-p\left(e^{a_{t}}-1\right)\right] A_{t}(h)+ \\
+\left(1-\tau_{k, t}\right) R_{t} K_{t-1}(h)+\tau_{k, t} \delta P_{I, t} K_{t-1}(h)+\Pi_{t}(h)
\end{gathered}
$$

\subsection{National Welfare Measure}

A natural (and commonly used) measure of the national welfare is the aggregate utility of all the domestic households. Letting the aggregate disutility of work be denoted as $A L_{j}{ }^{14}$, the value function that measures national welfare can be written as

$$
V_{t}=\max E_{t} \sum_{j=t}^{\infty} \beta^{j-t}\left\{\frac{M C_{j}^{1-\Theta}}{1-\Theta}-\frac{1}{1+\chi} A L_{j}\right\}
$$

\footnotetext{
${ }^{13}$ Equilibrium dynamics of a small open economy with incomplete asset markets generally include a random walk component; the transaction cost modification guarantees stationary of the model. See Schmitt-Grohé and Uribe (2003) for explicit treatment of the problem.

$$
\begin{aligned}
& { }^{14} A L_{j}=\left(\frac{N_{j}}{M}\right)^{1+\chi} D W_{j}, \quad \text { where } D W_{j}=(1-\omega) M\left(\frac{\tilde{W}_{j}}{W_{j}}\right)^{-\phi(1+\chi)}+ \\
& \omega\left(\frac{W_{j-1}}{W_{j}}\right)^{-\phi(1+\chi)} D W_{j-1} \text { and } N_{t}=\int_{0}^{1} N_{t}(f) d f .
\end{aligned}
$$
}


This value function will be used to make quantifiable comparisons of consumer welfare across different specifications of the two economies. To see how this can be done, let $\tilde{V}_{t}$ correspond to some benchmark specification of the domestic economy (for example, with no wage or price rigidities, so $\alpha=\omega=0$ ) and let $V_{t}$ be the value function from a different specification (to follow the above example, let $\alpha=\omega=0.5$ ). Denote by $\tilde{C}_{t}$ and $C_{t}$ household consumption, and by $\widetilde{A L}_{t}$ and $A L_{t}$ aggregate labor effort in these two economies, respectively. Finally, let $\epsilon$ be a number such that consumers are indifferent between receiving consumption streams $\tilde{C}_{j}$ and $(1+\epsilon) C_{j}$ for all $j \in(t ; \infty)$ :

$$
\begin{gathered}
\tilde{V}_{t}=E_{t} \sum_{j=t}^{\infty} \beta^{j-t}\left\{\frac{M \tilde{C}_{j}^{1-\Theta}}{1-\Theta}-\frac{1}{1+\chi} \widetilde{A L}_{j}\right\}= \\
=E_{t} \sum_{j=t}^{\infty} \beta^{j-t}\left\{\frac{M\left((1+\epsilon) C_{j}\right)^{1-\Theta}}{1-\Theta}-\frac{1}{1+\chi} A L_{j}\right\}
\end{gathered}
$$

The two value functions are equalized by adjusting only the stream of consumption, holding labor efforts unchanged. Therefore, $\epsilon$ can be interpreted as the fraction of consumption each household is willing to give up in order to move to the benchmark economy, keeping its labor supply stream fixed.

In the case of $\log$ utility, the expression for $\epsilon$ simplifies to the difference between the two value functions:

$$
\epsilon=V_{t}-\tilde{V}_{t}
$$

Notice that in general country size enters explicitly in the expression for the welfare function. Clearly, national welfare of a large country is greater than that of a small country, which makes it difficult to make comparisons between two asymmetric members of the currency union. However, for the purposes of quantifying the welfare effects of country size, I will keep the size of the home country constant at one $(M=1)$ while increasing the size of the foreign country $\left(M^{*}>1\right)$. If no other parameters of the model change, then (14) can be used to study the welfare of the home country as it becomes progressively smaller relative to the foreign country.

\section{Calibration}

This paper considers three different calibration schemes. As a benchmark case, I assume that both economies are symmetric with measure one of households in each country, since this will allow for easy comparisons of the results with the existing studies. In the other two specifications, the size of the foreign country is increased to $M^{*}=4$ and then to $M^{*}=19$, so that the home country makes up 20 and 5 percent of the union, respectively (corresponding to France and the Netherlands, for example). 


\begin{tabular}{|c|c|c|c|}
\hline Parameter & Description & Value & \\
\hline$\Theta$ & Relative risk aversion & 1.0 & \\
\hline$\chi$ & Inverse of Frisch labor elasticity & 3.0 & \\
\hline$\mu$ & Consumption home bias (domestic good) & 0.75 & \\
\hline$\beta$ & Discount factor & 0.99 & \\
\hline$\eta$ & $\begin{array}{l}\text { Elasticity of substitution between } \\
\text { home and foreign goods }\end{array}$ & 1.5 & \\
\hline$\nu$ & Capital share in the production function & 0.33 & \\
\hline$A$ & Matrix of technology coefficients & $\left(\begin{array}{l}0.83 \\
0.03\end{array}\right.$ & $\left.\begin{array}{l}0.39 \\
0.72\end{array}\right)$ \\
\hline$\delta$ & Capital depreciation rate & 0.025 & \\
\hline$\psi$ & Investment adjustment cost & 8.0 & \\
\hline$\sigma$ & $\begin{array}{l}\text { Elasticity of substitution between } \\
\text { goods varieties }\end{array}$ & 8.0 & \\
\hline$\phi$ & Elasticity of substitution between labor varieties & 7.0 & \\
\hline$\alpha$ & Price stickiness & 0.67 & \\
\hline$\omega$ & Wage stickiness & 0.80 & \\
\hline$\tau_{c}$ & Consumption tax & 0.17 & \\
\hline$\tau_{w}$ & Labor income tax & 0.36 & \\
\hline$\tau_{k}$ & Tax on capital (net of depreciation) & 0.39 & \\
\hline
\end{tabular}

Table 1: Benchmark parameter values

\subsection{Production and Preferences}

Each time period in the model corresponds to one quarter. I follow Canzoneri, Cumby and Diba (2004a) and Pappa (2004) in setting most of the parameters of the model; Table 1 summarizes their values. Many of these values are common in the literature on the European currency union; a few other parameters merit further description.

Empirical estimates put the value of Frisch labor elasticity anywhere between 0.05 and 0.35 . It has been noted by Canzoneri et al (2007), among others, that welfare costs are very sensitive to this parameter; therefore, I chose a conservative value $\chi^{-1}=0.33$ as the benchmark; robustness checks (not reported) indicate that this parameter has no impact on the differences in welfare costs of large and small countries.

The home bias parameter is set at $\mu=\mu^{*}=0.75$, which serves as a good lower bound on the share of imports in consumption in the EMU. I allow investors to have lower biases for the domestically produced good: $\vartheta=\vartheta^{*}=0.5$; finally, since governments consume mostly domestic goods, $\zeta=\zeta^{*}=0.9$.

As the relative size of the home country decreases, its share of imports still remains the same: $(1-\mu)=0.25$. However, foreign home bias $\mu^{*}$ is adjusted upward, which means that imports constitute a smaller share of foreign consumption. For example, when $M^{*}=4, \mu^{*}=0.94$. In the absence of this adjustment, foreign country would demand a disproportionately large share of 
home country output, which would raise home employment and wages and make it difficult to compare home welfare across the three relative size specifications.

Capital adjustment costs are calibrated so that the relative volatility of investment in the model is consistent with that in the data.

The cost of participating in the international asset markets, $p$, is set to $10^{-3}$ following Benigno (2001). This value implies a spread of 10 basis points between home and foreign yields, which is in line with recent empirical observations: Lane (2006) reports that the spread across national 10-year government bond yields in the EMU was 30 basis points in June of 2005.

The productivity process was approximated as a quasi-Solow residual, holding capital stock constant (a reasonable assumption for the estimation of shortrun correlations): $\ln \left(Z_{t}\right) \cong \ln \left(Y_{t}\right)-(1-\nu) \ln \left(N_{t}\right)$. I estimated several bivariate VARs of individual country productivities and the aggregate EMU productivity $Z_{t}^{*}$ (calculated using the aggregate EMU real output and employment $)^{15}$. Thus, the foreign productivity shock $\varepsilon_{z}^{*}$ in our model can be interpreted as the average technological improvement in the rest of the EMU vis-à-vis the home country. Variances of these shocks were estimated to lie in the following ranges: $\operatorname{Var}\left(\varepsilon_{z}\right) \in[0.000021,0.000128]$ with Portugal exhibiting the highest variance of productivity; $\operatorname{Var}\left(\varepsilon_{z}^{*}\right) \in 0.000015$ for the Euro aggregate; and $\operatorname{Cov}\left(\varepsilon_{z}, \varepsilon_{z}^{*}\right) \in[0.000008,0.000056]$. In the simulations, $\operatorname{Var}\left(\varepsilon_{z}\right)$ and $\operatorname{Cov}\left(\varepsilon_{z}, \varepsilon_{z}^{*}\right)$ are set to their lowest estimated values, so that the calculated costs of nominal inertia can be interpreted as the lower bounds for the true costs.

Finally, wage stickiness parameter $\omega$ has been set to 0.80 (which is slightly higher than the commonly used value of 0.75 ) to bring wage volatility in range of the data.

\subsection{Government Policies}

Fiscal policy was estimated using data from Finland, France, Ireland and the Netherlands; the choice of countries is based on the availability of fiscal data.

The ratio of government debt to GDP has to be stationary in the model; fiscal policy, therefore, must respond in some way to either deficit or debt. The reactions of government spending and (separately) transfers to the debt-to-GDP ratio are estimated to be significant in all four countries; responses of both variables to the deficit ratio are much smaller and not statistically significant in two of the four cases. (Estimation results are presented in Appendix B.) Therefore, in the model transfers respond to the deviation of debt ratio from its steadystate value. The latter is set at 60 percent of GDP in both economies, which corresponds to the Maastricht debt criterion and is roughly representative of the above four countries during the 1999-2004 period. This model does not capture all sources of revenues and outlays available to the European governments, and so cannot match all features of the observed fiscal policies. To achieve the 60 percent debt-to-GDP ratio, transfers are set equal to 10 percent of GDP

\footnotetext{
${ }^{15}$ Estimations presented below were carried out using 1980-2004 quarterly data; see appendix A for data description and sources.
} 
(compared with the EMU average of 17 percent). Of all the fiscal instruments, transfers play the least distortionary role in the model (they act as a lump-sum tax on consumers), and so adjusting their value has minimum impact on other variables.Tax rates in Table 1 represent the average of the corresponding values in the eleven EMU countries (Luxembourg not reported) during 1990-2000 ${ }^{16}$.

The parameters of the government policy functions are estimated to be as follows: $\rho_{g}=\rho_{t r}=0.9$ and $\operatorname{Var}\left(\varepsilon_{g}\right)=0.0082$. Responsiveness of transfers to the level of debt $\rho_{b}$ was set to 0.18 in order to satisfy the Blanchard-Kahn conditions.

The estimates of the Taylor rule parameters in equation (12) are $\rho_{i}=0.95$, $\varpi=1.4$ and $\operatorname{Var}\left(\varepsilon_{i}\right)=10^{-6}$ using the data from ten EMU countries. These findings are consistent with the existing literature: Duarte and Wolman (2002) use $\rho_{i}=0.91$ and $\varpi=1.31$. Coenen and Straub (2005) report $\rho_{i}$ to be as high as 0.96 using Bayesian estimation methods.

\subsection{Demand Shocks}

It has been noted (see, for example, Canzoneri et al (2006)) that the standard NNS models are unable to match the observed positive correlation between output and inflation because they do not properly capture aggregate demand shocks. For this reason, I introduce a disturbance to consumer preferences when studying the incomplete asset market setting ${ }^{17}$. By assumption, a positive shock increases demand in both countries for Home good $\left(Y_{H}\right)$ by influencing the home bias coefficients:

$$
\begin{aligned}
\mu_{t} & =\bar{\mu} \exp \left(\varrho_{t}\right), \quad \mu_{t}^{*}=\overline{\mu^{*}} / \exp \left(\varrho_{t}\right) \\
\varrho_{t} & =0.9 \varrho_{t-1}+\varepsilon_{\varrho, t}
\end{aligned}
$$

This particular form of the shock is meant to capture shifts in consumer preferences that can result from deeper trade integration; for example, more competition between countries increases elasticity of demand for local goods ${ }^{18}$.

The same adjustment is made to the investment and government spending home biases. I set $E(\varrho)=0$ and $\operatorname{Var}\left(\varepsilon_{\varrho}\right)=0.01$. Since this shock cannot be measured empirically, its volatility was chosen to match the standard deviation of output in the model and in (the mid-range of) the data.

The model was solved numerically using Dynare (see Collard and Juillard (2003)). First order approximations were used to compute moments, variance decompositions and impulse response functions presented below; value functions were calculated using second-order approximations to the model.

\footnotetext{
${ }^{16}$ Source: Carey and Rabesona (2002).

${ }^{17} \mathrm{With}$ complete asset markets, preference shocks cause wealth transfers between the two countries and so have no impact on relative consumption streams.

${ }^{18}$ A similar shock structure has been explored in Stockman and Tesar (1995).
} 


\section{Simulation Results}

This section discusses the differences in welfare costs predicted by the model for different country sizes, as well as the sensitivity of these predictions to alternative specification of international asset market structure and monetary policy setup. I calculate the responses of prices to each shock and elucidate the cross-country linkages that help small member states to mitigate the effects of economic disturbances originating in bigger countries.

Before proceeding, it is important to note that the choice and calibration of shocks in the model will have first-order effects on welfare numbers and consequently on policy suggestions. Chari, Kehoe and McGrattan (2008) point out that many New Keynesian DSGE models suffer from presence of what the authors call "dubiously structural" shocks, which are not derived from easily interpretable primitives and therefore may give rise to conflicting policy prescriptions. For this reason, I include only three arguably non-controversial and easily measurable shocks in the benchmark specification of the model: technology, interest rate and government purchases. Following this, a non-observable demand shock will be studied as a matter of model robustness.

\subsection{Matching the Data}

All specifications of the model result in the following decomposition of steady state GDP (in both countries): consumption share of $63 \%$, investment share of $17 \%$ and government spending share of $20 \%$; the corresponding EMU averages for the period 2002-2006 are 57\%, 21\% and 20\% (source: Eurostat).

Table 2 shows that the model approximates the volatility of the actual data ${ }^{19}$ reasonably well, except in the case of employment, which is almost twice as volatile in the model as it is in the data. Adjusting the value of the Frisch labor elasticity (between 0.05 and 0.35 , the empirically estimated range) produces virtually no effect on the standard deviation of employment.

On the correlations front, the most noticeable inconsistencies arise with respect to inflation and interest rate. As mentioned above, the sign of outputinflation and output-interest rate correlations has been a rather controversial issue in New-Keynesian models. ${ }^{20}$ Both correlations are positive in the data; this model, however, is incapable of correctly matching the output-interest rate correlation, and overshoots the size of output-inflation correlation.

A standard one-sector New-Keynesian model predicts that a positive supply shock creates an increase in output and a drop in price level; interest rates then move down in response to lower inflation (countercyclical movement). Demand shocks, on the other hand, put an upward pressure on output, prices and interest rates and create procyclical movements in these variables. Finally, a monetary policy shock causes a reduction in output and inflation; it is another source of

\footnotetext{
${ }^{19}$ The ranges presented in the table refer to the dispersion of corresponding moments across Finland, France, Ireland and Netherlands (countries for which all relevant data are available).

${ }^{20}$ See Canzoneri et al (2006) for a detailed study of the signs of these correlations in NewKeynesian models.
} 


\begin{tabular}{|l|cccc|cccc|}
\hline & \multicolumn{4}{|c|}{ Standard Deviations } & \multicolumn{4}{c|}{ Correlation w/Output } \\
\cline { 2 - 9 } & Actual Data & $\kappa=\frac{1}{2}$ & $\kappa=\frac{1}{5}$ & $\kappa=\frac{1}{20}$ & Actual Data & $\kappa=\frac{1}{2}$ & $\kappa=\frac{1}{5}$ & $\kappa=\frac{1}{20}$ \\
\hline \hline$Y_{H}$ & $0.010-0.028$ & 0.022 & 0.022 & 0.022 & 1.000 & 1.000 & 1.000 & 1.000 \\
$C_{H}$ & $0.014-0.029$ & 0.017 & 0.017 & 0.017 & $0.507-0.820$ & 0.991 & 0.991 & 0.991 \\
$I_{H}$ & $0.035-0.078$ & 0.064 & 0.064 & 0.064 & $0.570-0.907$ & 0.989 & 0.990 & 0.990 \\
$N_{H}$ & $0.006-0.019$ & 0.032 & 0.032 & 0.032 & $0.424-0.824$ & 0.944 & 0.943 & 0.943 \\
$W_{H}$ & $0.006-0.016$ & 0.006 & 0.006 & 0.006 & $-0.197-0.765$ & -0.354 & -0.360 & -0.363 \\
$\pi_{H}$ & $0.003-0.006$ & 0.004 & 0.004 & 0.004 & $0.015-0.264$ & 0.737 & 0.743 & 0.747 \\
$i$ & $0.002-0.005$ & 0.001 & 0.001 & 0.001 & $0.054-0.460$ & -0.990 & -0.983 & -0.978 \\
\hline
\end{tabular}

Table 2: Kappa is the relative size of the home economy. Moments of the actual and simulated data under benchmark calibration (complete markets, no preference shocks).

countercyclical movement of the interest rate. The sign and magnitude of the resulting correlations between output, inflation and the interest rate, therefore, depend on the relative importance of the three types of shocks.

Historically, New-Keynesian models have been unable to properly capture demand-side shocks; it is also true of this model. Variance decompositions, presented in the next subsection, show that government (demand) shocks have a relatively insignificant impact on the key variables of the model; the latter are driven primarily by monetary policy disturbances and (to a lesser extent) by technological shocks.

Monetary policy is given additional importance by the omission of the output gap term; this form of Taylor rule creates a strong negative correlation between interest rate and output. This issue will be addressed again below when I present the variance decompositions of several key variables following the shocks modeled in the paper.

\subsection{Welfare Implications}

Having described the specifications and workings of the model, the first question to be answered is: what are the resulting costs of nominal (wage and price) inertia, and do they depend on the country size?

Canzoneri et al (2004a) have studied the interactions of twelve separate fiscal policies and the common monetary rule in the EMU. They found that large EMU member states are better off than smaller ones because inflation rates in the former are more highly correlated with the aggregate Euro area inflation to which the ECB reacts. Since prices, wages and fiscal policy cannot move instantly to counteract country-specific shocks, the EMU members rely on the central bank policy to offset their high-frequency economic disturbances. However, a German inflation shock would elicit a stronger interest rate response than a similar shock in Belgium, resulting in relatively high welfare costs of nominal rigidities in the latter country. The authors calculate that the welfare costs of business cycles can be up to four times higher in an "average-size" EMU 
country than in a "large" one.

There are two reasons why the above findings may exaggerate welfare losses of the small EMU countries. First, the authors present a partial-equilibrium model, which potentially ignores cross-country links that can offset idiosyncratic shocks even before the ECB steps in. Indeed, as will be shown below, there exists a strong positive correlation between home and foreign inflations that causes the central bank to respond to home country shocks even when the country is very small. Second, if technological innovations are positively correlated across member states (as is the case in the OECD data), then, as in the previous example, German shock would spill over into Belgium almost instantaneously, and the resulting central bank response would be helpful to both countries.

Duarte and Wolman (2002) consider a two-country DSGE model in order to explain the observed inflation differentials in the EMU and their possible dependence on country size. The authors find that smaller countries experience higher volatility of inflation following a shock to productivity. The authors do not calculate the resulting welfare costs of nominal rigidities, but at least within my framework, their results would imply bigger losses for small EMU member states: the same arguments used in the preceding paragraphs would suggest that the response of the ECB would be skewed towards larger countries.

In this paper, inflation volatility is uncorrelated with country size (this result is discussed further below). The reason is that the model lacks two potential sources of inflation variability which are present in Duarte and Wolman (2002): non-traded goods sectors (which allow for the Balassa-Samuelson effect) and segmented markets for traded goods (with the potential failure of the Law of One Price). I dispense with these features for two reasons: first, Altissimo et al. (2005) note that the standard two country models cannot properly capture the Balassa-Samuelson effect because they don't possess many necessary features (such as international capital mobility and homogeneous traded goods markets). The authors also note that the magnitude of the terms-of-trade effect usually overshadows the Balassa-Samuelson effect. Secondly, Duarte and Wolman find that their model does not generate significant deviations from the LoOP and that it overestimates the volatility of inflation gaps across countries.

\begin{tabular}{|c|c|c|c|c|c|c|}
\hline & Benchmark & Counterfactual & I & II & III & IV \\
\hline \hline$\kappa=0.5$ & 1.81 & 1.79 & 1.97 & 1.66 & 2.03 & 1.94 \\
$\kappa=0.2$ & 1.80 & 1.79 & 2.00 & 1.64 & 2.09 & 1.95 \\
$\kappa=0.05$ & 1.80 & 1.80 & 2.02 & 1.64 & 2.13 & 1.96 \\
\hline
\end{tabular}

Table 3: Welfare costs of nominal intertia, percent of consumption. I: incomplete asset markets and demand shocks; II: independent monetary policies with incomplete markets; III: (II) with imports/exports elasticity of substitution equal to 0.9 ; III: benchmark with imports share equal to 40 percent.

Let's now turn to the main results. Figure 2 presents the relationship between the relative size of the Home country $\left(\frac{M}{M+M^{*}}\right)$ and its welfare cost of nominal rigidities. Calculations, reported in Table 3, show that when asset 


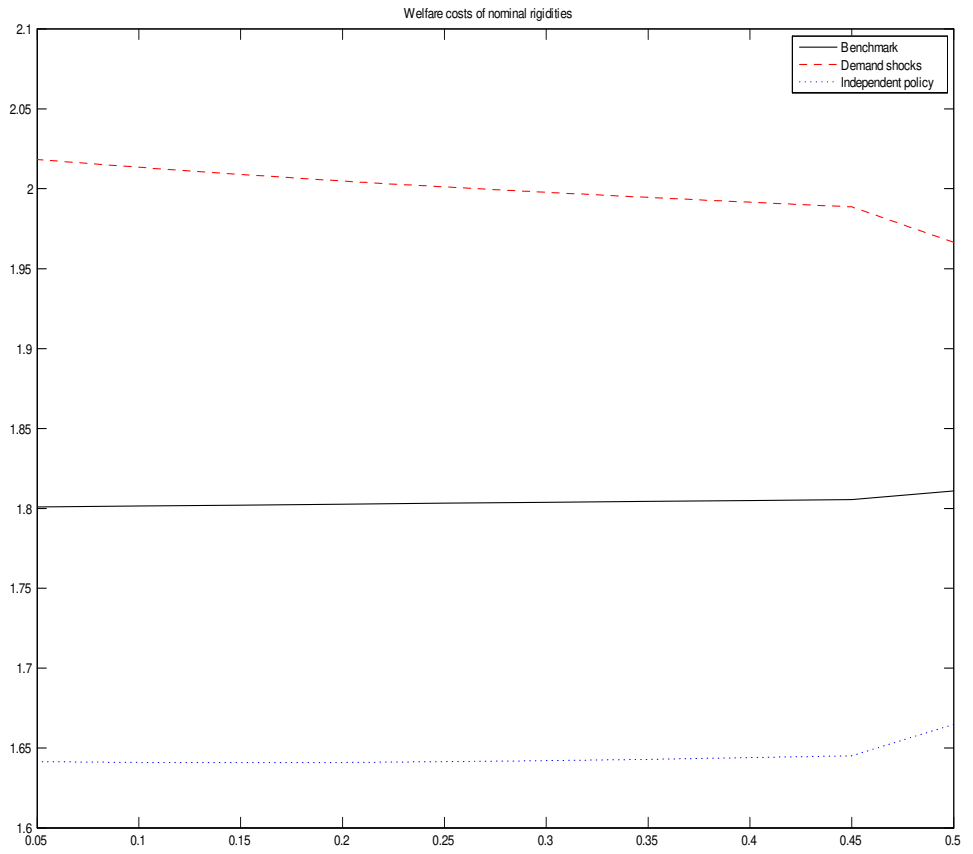

Figure 2: Welfare costs of nominal rigidities as a function of relative country size.

markets are complete, welfare costs are virtually independent of country size (smaller countries are better off by 0.01 percent of steady state consumption). Variance decompositions for the benchmark calibration, reported in Table 4, shed some light on this rather surprising result.

The measure of welfare in (13) is computed using the expected streams of consumption and work hours. As was mentioned above, complete international risk sharing equates marginal utilities (and, in this model, levels) of per-capita consumption across the two countries at all times, and so serves as a buffer against idiosyncratic shocks. Additionally, as can be seen from Table 4, volatilities of consumption and hours are influenced mostly by the interest rate, which, being common to both countries, elicits identical responses of consumption and hours at home and abroad (see Figure 3). Consequently, the monetary policy shock does not favor the larger country and does not cause dispersion in welfare costs.

The interest rate shock plays the dominant role in this model; this result is qualitatively consistent with most two-country New-Keynesian models, although the numbers reported in Table 4 are somewhat higher than usual. This 


\begin{tabular}{|c|c|c|c||c|c|c||c|c|c|}
\hline & \multicolumn{4}{|c||}{$\kappa=\frac{1}{2}$} & \multicolumn{3}{c||}{$\kappa=\frac{1}{5}$} & \multicolumn{3}{c|}{$\kappa=\frac{1}{20}$} \\
\cline { 2 - 9 } & $\varepsilon_{z}+\varepsilon_{z}^{*}$ & $\varepsilon_{i}$ & $\varepsilon_{g}+\varepsilon_{g}^{*}$ & $\varepsilon_{z}+\varepsilon_{z}^{*}$ & $\varepsilon_{i}$ & $\varepsilon_{g}+\varepsilon_{g}^{*}$ & $\varepsilon_{z}+\varepsilon_{z}^{*}$ & $\varepsilon_{i}$ & $\varepsilon_{g}+\varepsilon_{g}^{*}$ \\
\hline \hline$C_{H}$ & 8.4 & 91.5 & 0.1 & 7.3 & 92.6 & 0.1 & 6.8 & 93.1 & 0.1 \\
$N_{H}$ & 1.3 & 98.0 & 0.6 & 1.6 & 97.7 & 0.7 & 1.8 & 97.5 & 0.7 \\
$W_{H}$ & 49.8 & 49.9 & 0.2 & 51.0 & 48.8 & 0.2 & 51.6 & 48.2 & 0.3 \\
$\pi_{H}$ & 19.5 & 80.2 & 0.3 & 20.7 & 79.0 & 0.3 & 21.3 & 78.4 & 0.3 \\
$i$ & 5.0 & 94.9 & 0.1 & 3.0 & 96.9 & 0.1 & 2.3 & 97.5 & 0.2 \\
\hline
\end{tabular}

Table 4: Variance decomposition for the benchmark calibration with nominal rigidities, infinite horizon (percent). Percentages in the table may not add up to 100 due to rounding errors.

is partly due to the fact that my estimations indicate higher persistence in the ECB Taylor Rule, and lower AR(1) coefficients for the productivity processes than what is reported in, for example, Canzoneri et al (2004a). If I drop the parameters in the Taylor Rule to the U.S. levels, the resulting variance decompositions fall in line with existing literature without affecting the main conclusions of this paper.

\subsection{The Feedback Channel}

The case of technological shocks is a more interesting one because it highlights the feedback channel between the two economies that magnifies the interest rate response to the small country's inflation. In what follows, I will consider the middle-of-the-road "20-80" case, since it is applicable to the largest EMU countries (Germany, France and Italy); however, the same arguments hold for the other two specifications.

At first glance, the sequence of events should be as follows: when the (small) home country is hit with a positive productivity shock, the price of its product declines, causing domestic deflation. The consequent wealth effect increases demand for home and foreign goods in both countries. As a result, the foreign producers effectively experience an increase in demand and raise prices in response. The weighted area-wide deflation will be smaller than in the home country; if the latter is very small, the area-wide consumer price index may even increase, prompting an upended (from the perspective of the home country) response from the central bank. Thus, it would seem that small countries would not get any help from the ECB following a domestic productivity disturbance.

Upon more careful examination, however, it turns out that the foreign country also experiences deflation, and consequently the interest rate unambiguously declines (Figure 4). To see this, it is helpful to consider what happens to the two PPI inflations. The Philips curve for the home country (derived by loglinearizing equations (2) and (3)) takes the form

$$
\pi_{H, t}=\frac{(1-\alpha \beta)(1-\alpha)}{\alpha} \frac{M C_{t}}{P_{H, t}}+\beta E_{t} \pi_{H, t+1},
$$



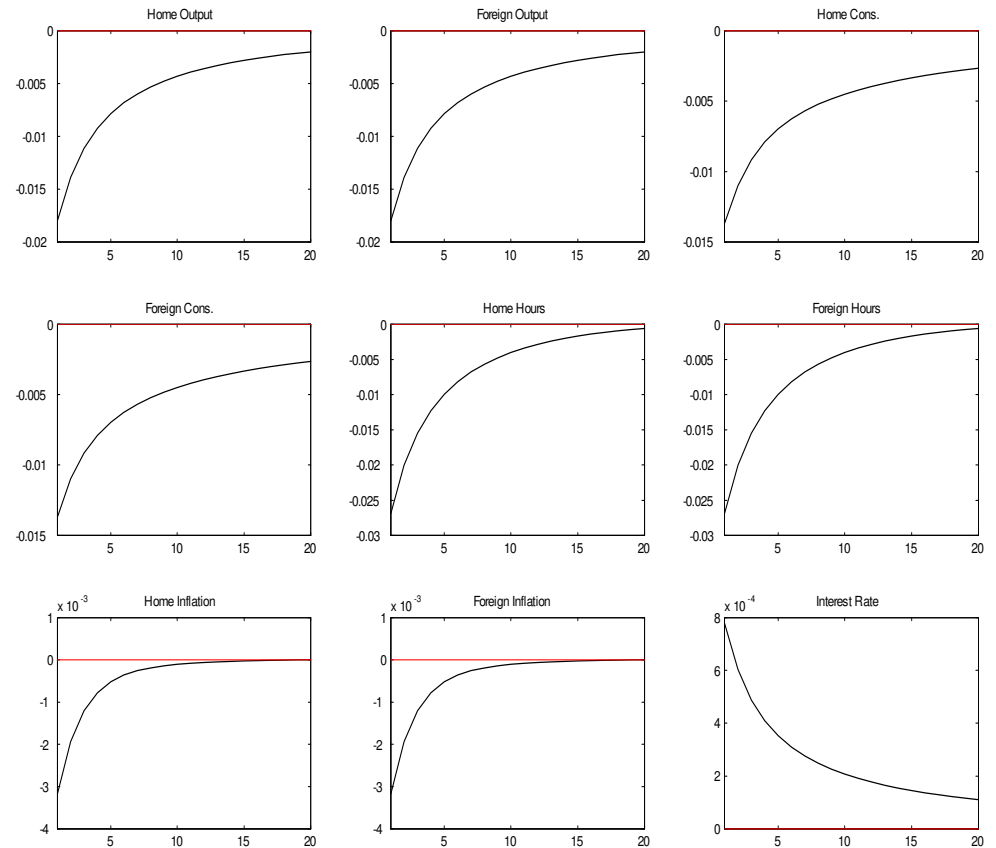

Figure 3: Impulse response functions of several key variables following a shock to the interest rate in the "20-80" scenario (with complete markets).

where $\pi_{H, t}$ refers to the home country's PPI inflation at date $t$; an analogous equation holds for the foreign country. In other words, today's PPI inflation depends on the discounted expectations of future real marginal costs. Because of the technological spillovers between the two countries, a positive productivity shock in the home country almost immediately translates into higher productivity abroad, which reduces the foreign marginal cost. Moreover, price and wage stickiness both slow down the rise in foreign factor prices, which would normally follow an increase in demand for the foreign good. Together, these forces make the present value of foreign future marginal costs negative, resulting in the foreign PPI deflation (Figure 5). Consequently, both CPIs, which are weighted averages of the two PPIs, also fall and therefore cause the central bank to lower the interest rate.

The same argument holds in the other direction: productivity shocks originating abroad very quickly affect home technology, causing the two CPI inflations to move together and consequently prompting an appropriate (for both countries) response from the central bank. 

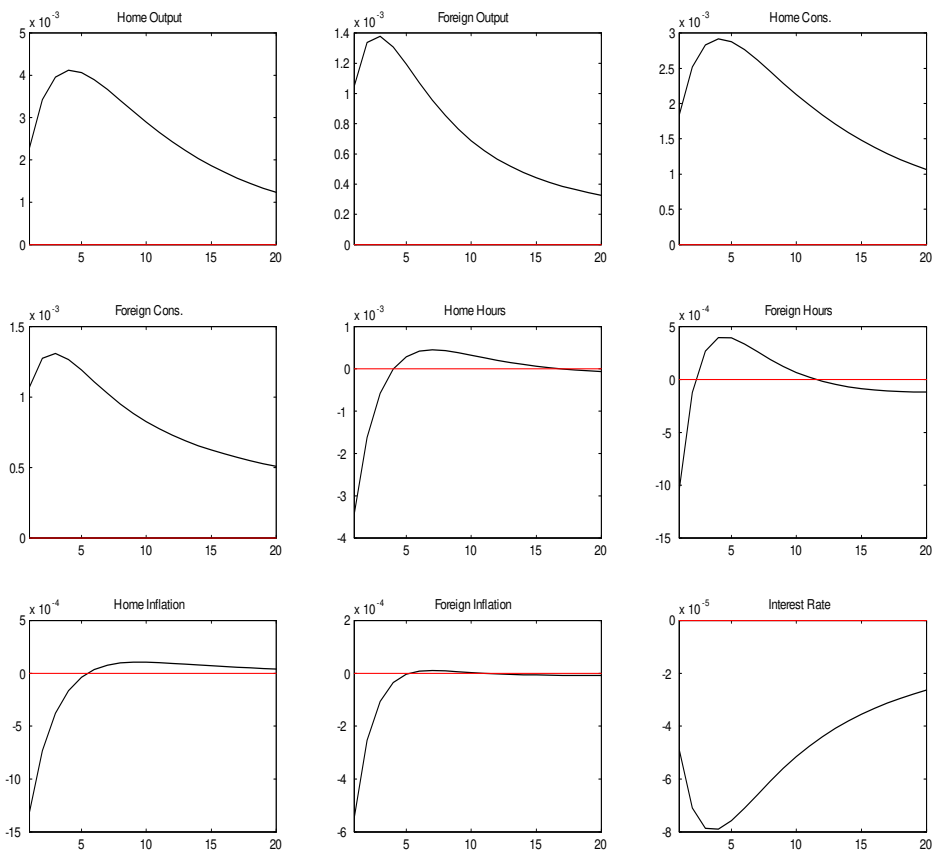

Figure 4: Impulse response functions of several key variables following a shock to home productivity in the "20-80" scenario (with complete markets).

Simulation of the counterfactual (setting to zero the correlation of productivity shocks and the off-diagonal elements of technology matrix $A$ ) confirms this result for all studied specifications of the model, including the robustness exercises discussed below: welfare costs of small countries fall below those of large countries (the difference again is very small, less than 0.01 percent of consumption). Table 3 presents the results of the counterfactual simulation for the benchmark calibration.

However, a word of caution is in order: the model overstates the importance of technology in smoothing inflation differentials. Canzoneri et al. (2006) estimate the correlation between EMU-wide and individual countries' inflations:

$$
\pi_{t}^{\text {euro }}=\theta_{i} \pi_{i, t}+\varepsilon_{i, t}^{\pi} .
$$

The authors find that this correlation is much larger for countries like France and Germany $\left(\theta_{i}=0.7\right)$ than for small EMU members like Ireland and Portugal $\left(\theta_{i}=0.2\right)$. In contrast to this, calculations based on my model simulations indicate that $\theta_{i}$ does not fall below 0.9 even when the country is only 5 percent 

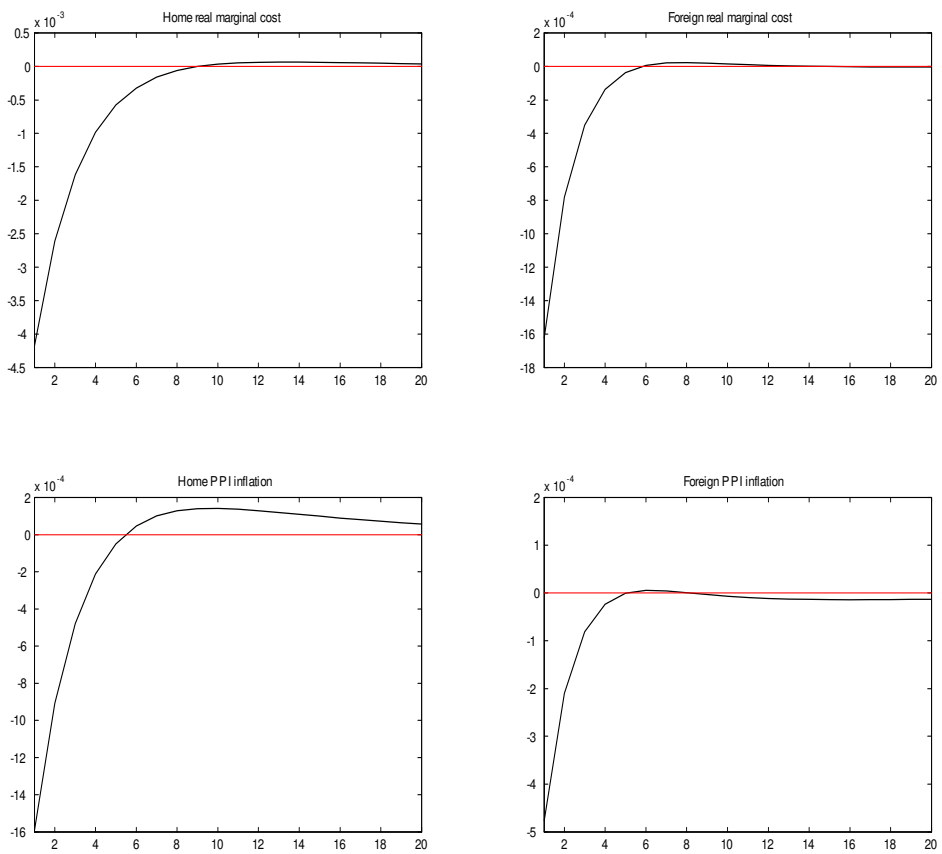

Figure 5: Impulse response functions of marginal costs and PPI inflations following a shock to home productivity in the "20-80" scenario (with complete markets).

of the size of the union. Insofar as my estimates of correlations in technological processes differ from the above study, I should in fact find higher correlations between national and euro-wide inflations. However, if the model is failing to capture some country-specific shocks that are present in the data, the reported estimates of the differences in welfare costs should be interpreted as the lower bounds for their true values.

Productivity typically plays a dominant role in NNS models; as mentioned above, attempts to beef up the demand shocks haven't been entirely satisfactory. It is then entirely plausible that the standard New-Keynesian models are incapable of properly capturing differences in welfare costs of different countries. Further research in this direction is needed to shed more light on the influence of relative country size on welfare costs in a monetary union. 


\subsection{Demand Shocks}

Let's now turn to a more realistic scenario of incomplete international asset markets. The moments and variance decompositions of all variables are identical to the ones reported above.
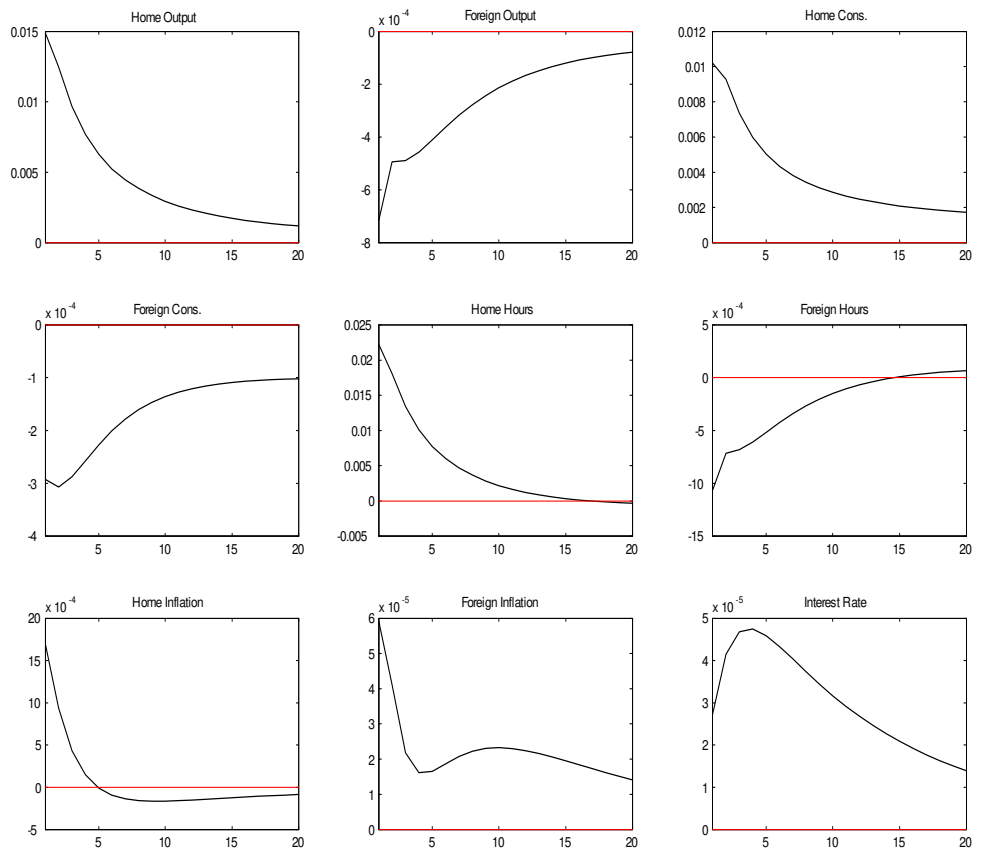

Figure 6: Impulse response functions of several key variables following an increase in international demand for the home good in the "20-80" incomplete markets scenario.

Following the addition of the demand shock (illustrated in Figure 6), smaller countries do incur higher welfare costs, but the difference in these costs across the studied country sizes is negligible at 0.05 percent of consumption. The resulting increase in home output gradually disappears over the period of 20 quarters. An increase in home inflation more than offsets a (ten times smaller) decline in the foreign price level, prompting the central bank to increase the interest rate. Even though the monetary authority does respond to the disturbance in the home economy, the additional fluctuations in consumption and hours caused by demand shocks (and reported in Table 5) coupled with non-zero costs of lending and borrowing in international markets add almost 0.2 percentage points to welfare costs of home residents, compared with the benchmark 
setup.

\begin{tabular}{|c|c|c|c|c|}
\hline \multirow{2}{*}{} & \multicolumn{4}{|c|}{$" 20-80 "$} \\
\cline { 2 - 5 } & $\varepsilon_{z}+\varepsilon_{z}^{*}$ & $\varepsilon_{i}$ & $\varepsilon_{p}$ & $\varepsilon_{g}+\varepsilon_{g}^{*}$ \\
\hline \hline$C_{H}$ & 10.4 & 87.7 & 1.7 & 0.2 \\
$N_{H}$ & 1.1 & 79.3 & 19.1 & 0.5 \\
\hline$W_{H}$ & 48.2 & 46.7 & 4.9 & 0.2 \\
\hline$\pi_{H}$ & 17.6 & 74.2 & 7.9 & 0.3 \\
\hline$i$ & 2.9 & 97.0 & 0.0 & 0.1 \\
\hline
\end{tabular}

Table 5: Variance decomposition for the "20-80" scenario when asset markets are incomplete, infinite horizon (percent). Percentages in the table may not add up to 100 due to rounding errors.

These results are in line with the findings of Benigno (2001): he reports that incomplete markets cost between 0.07 and 0.7 percent of consumption. As Column I of Table 3 indicates, the costs of going from complete to incomplete markets do not exceed 0.2 percent of consumption for large or small countries.

How does technology play into these numbers? Following the same counterfactual simulation as above (removing correlations in the productivity processes and innovations), I find that the welfare gap between small and large countries increases (to the detriment of the former) by another 0.01 percent of steady state consumption, a magnitude identical to the results reported in the previous section.

\section{Robustness Checks}

\subsection{Independent Monetary Policies}

In the aftermath of the credit crisis that had swept through most of the world in 2008, several EMU members as well as some economists have been publicly discussing the option of quitting the Euro area to better stabilize their economies by regaining their own monetary policy.

In the context of the model, the results of Section 4.4 do indeed suggest that small countries incur higher (albeit very marginally) costs of nominal rigidities. How would the relationship between these costs and country size change if the two economies could pursue independent monetary policies?

To answer this question, I modify the structure of the model by introducing a nominal exchange rate between the two countries and a second policy rule that governs the foreign interest rate $i_{t}^{*}$. More specifically, each of the two central banks follows the rule given by (12), with the same calibration as in the benchmark specification. Asset markets are again incomplete, with domestic residents paying a premium (which depends on their international portfolio) over the foreign rate $i_{t}^{*}$.

Column II of Table 3 and Figure 2 present the results of this exercise. Ceteris paribus, smaller countries fare slightly better than large ones when each country 
has its own monetary policy. It is tempting to interpret these results as suggesting that the EMU countries give up close to 0.4 percent of consumption to be a part of the union. However, this study focuses on welfare differences between countries of different sizes under various scenarios rather than on which scenario delivers the lowest costs. The absolute value of the costs depends not only on the structure of the model, but also on the parameterization; the question of net total benefits of a monetary union is beyond the scope of this paper.

Based on the results of this section, one can conclude that, whatever the pros and cons of independent monetary policy may be, the costs of nominal rigidities are virtually independent of country size both in and out of a currency union.

\subsection{Parameter Values}

Researchers working with DSGE models in international setting have pointed out that model predictions and the corresponding policy prescriptions can be sensitive to several parameter values. Here I check whether the results of the above simulations would change following recalibration of two well-studied parameters: elasticity of substitution between home and foreign goods, and the degree of home bias.

Tille (2001) points out that transmission mechanism and welfare effects of monetary and fiscal policy shocks depend on the degree of substitutability between local and foreign goods, which affects the ability of households to switch between these goods following a change in the terms of trade. In the context of the present model, terms of trade are affected by shocks to demand (both public and private) and technology. Column III of Table 3 shows the results of the "worst case scenario" of incomplete markets subject to demand shocks and low elasticity of imports/exports substitution. As expected, limiting the extent of consumption-switching after a terms-of-trade change lowers welfare of all countries, with smaller ones being affected more, since imports constitute a larger share of their consumption. However, even with this unfavorable setup, small countries fare worse than large ones by only 0.09 percent of steady state consumption. Switching to independent monetary policy yields results similar to the ones reported in Column II: absolute costs fall to 1.64 percent, with the difference between large and small countries falling to 0.007 percent.

I next turn to the impact of trade openness on the differences in the costs of welfare between the two monetary union members. Figure 1 shows that the shares of exports and imports vary significantly across European countries. As documented in the literature ${ }^{21}$, the presence of home bias in the international consumption aggregator (5) generates endogenous movements of the real exchange rate in response to changes in terms of trade; real exchange rate, in turn, affects relative consumptions in the two countries ${ }^{22}$.

In column IV of Table 3 , the share of imports in the home country is increased to 40 percent while maintaining the incomplete markets and demand shocks

\footnotetext{
${ }^{21}$ See, for example, Faia and Monacelli (2008) and Mykhaylova (2009).

${ }^{22}$ International asset markets are incomplete, so we do not get the usual link between home and foreign consumption levels, $C_{t}=Q_{t} C_{t}^{*}$.
} 
assumptions. The welfare costs decrease slightly for all country sizes and become more similar: if a country is relatively more open to trade, its CPI inflation is more correlated with foreign inflation. A reduction in inflation differentials makes the job of the common monetary policy easier and increases the degree of implicit international risk-sharing.

This works is not aiming at estimating welfare costs of price and wage inertia per se. The robustness checks, however, show that the main finding - that difference in welfare costs across small and large EMU countries are negligent are independent of the modeling assumptions.

\section{Conclusion}

I have employed a two-country general equilibrium model of a currency union to answer the question of how (if at all) country size affects welfare costs of nominal rigidities in the EMU member states. The main result - that there are virtually no differences in these costs between small and large countries - is primarily driven by two features of the model.

First, idiosyncratic productivity shocks, which have the potential to drive a wedge between welfare measures of large and small countries, are mitigated by cross-country productivity links. EMU members have experienced an increase in the degree of alignment of their business cycles, as is reported in Lane (2006) and as seen in the estimates of productivity processes. Insofar as productivity shocks are among the main causes of business cycles, the model is able to explain why welfare costs of nominal rigidities are so similar across countries of different sizes: technology spillovers bring national output and price movements closer in sync and so help to make the interest rate response appropriate for both member countries.

Secondly, the model indicates that monetary policy shocks (which are symmetric across all union countries) account for most of the variability of output, consumption and hours and so affect welfare measures of all countries equally.

In the presence of incomplete markets and consumption demand shocks, I find that gains in welfare for small countries relative to large ones from retaining independent monetary policies are very small. It seems that costs associated with nominal rigidities fall equally on all countries studied in this paper, regardless of whether they are inside or outside of the monetary union.

Some caution needs to be taken when interpreting the results of this study. As is common in New-Keynesian literature, the model does not properly capture the observed cyclical correlation between output and interest rate, and overestimates the output-inflation correlation due to the dominance of interest rate movements. Technological shocks are likely to play a larger role in driving output fluctuations than my results suggest; if the resulting price movements are not as responsive to GDP fluctuations as the simulations show, monetary policy may be less effective in smoothing business cycles, and so welfare costs of nominal rigidities may be higher than this paper predicts. 


\section{References}

[1] Altissimo, F., Benigno, P. Rodriguez-Palenzuela, D., 2005. Long-Run Determinants of Inflation Differentials in a Monetary Union. NBER Working Paper No. 11473.

[2] Andrés, J., López-Salido, D., Vallés, J., 2006. Money in an Estimated Business Cycle Model of the Euro Area. Economic Journal 116, 457-477.

[3] Andrés, J., Ortega, E., Vallés, J., 2006. Competition and Inflation Differentials in EMU. Banco de España Working Paper No. 0301.

[4] Benigno, P., 2004. Optimal Monetary Policy in a Currency Area. Journal of International Economics 63, 293-320.

[5] Benigno, P., 2001. Price Stability with Imperfect Financial Integration, CERP Discussion Paper No. 2854.

[6] Calvo, G., 1983. Staggered Prices in a Utility Maximizing Framework. Journal of Monetary Economics 12, 383-398.

[7] Canzoneri, M., Cumby, R., Diba, B., Mykhaylova, O., 2006. New Keynesian Explanations of Cyclical Movements in Aggregate Inflation and Regional Inflation Differentials. Open Economies Review 17, 27-55.

[8] Canzoneri, M., Cumby, R., Diba, B., 2004a. Macroeconomic Policy in the European Monetary Union. Prepared for the NBER's ISOM in Reykjavik, Iceland, June 18-19, 2004.

[9] Canzoneri, M., Cumby, R., Diba, B., 2007. The Cost of Nominal Inertia in NNS Models. Journal of Money, Credit and Banking, 39, 1563-1586.

[10] Carey, D., Rabesona, J., 2002. Tax Ratios on Labour and Capital Income and on Consumption. OECD Economic Studies 35, 2002/2, 129-174.

[11] Chari, V.V., Kehoe, P., McGrattan, E., 2009. New Keynesian Models: Not Yet Useful for Policy Analysis. American Economic Journal: Macroeconomics, 1, 242-266.

[12] Chari, V.V., Kehoe, P., McGrattan, E., 2002. Can Sticky Price Models Generate Volatile and Persistent Exchange Rates? Review of Economic Studies 69, 533-63.

[13] Coenen, G., Straun, R., 2005. Does government spending crowd in private consumption? Theory and empirical evidence for the euro area. European Central Bank Working Paper No. 180.

[14] Collard, F., Juillard, M., 2003. Stochastic simulations with DYNARE. A practical guide. CEPREMAP, 2003. (http://www.cepremap.cnrs.fr/dynare/) 
[15] Duarte, M., 2003. The Euro and Inflation Divergence in Europe. Federal Reserve Bank of Richmond Economic Quarterly 89/3, 53-70.

[16] Duarte, M., Wolman, A., 2002. Regional Inflation in a Currency Union: Fiscal Policy vs. Fundamentals. European Central Bank Working Paper No. 180.

[17] Duarte, M., Wolman, A., 2003. Fiscal Policy and Regional Inflation in a Currency Union. Federal Reserve Bank of Richmond Working Paper No. 03-11.

[18] Faia, E., Monacelli, T., 2008. Optimal Monetary Policy in a Small Open Economy with Home Bias. Journal of Money Credit and Banking 40, 721750 .

[19] Ferrero, A., 2005. Fiscal and Monetary Rules For a Currency Union. European Central Bank Working Paper No. 502.

[20] Gerdesmeier, D., Roffia, B., 2004. Empirical estimates of reaction functions for the euro area. Swiss Journal of Economics and Statistics 1, 37-66.

[21] Gerlach-Kristen, P., 2003. Interest rate reaction functions and the Taylor rule in the euro area. European Central Bank Working Paper No. 258.

[22] Hayo, B., Hofmann, B., 2006. Comparing monetary policy reaction functions: ECB versus Bundesbank. Empirical Economics 31, 645-662.

[23] Lane, P., 2006. The Real Effects of EMU. IIIS Discussion Paper No. 115.

[24] Mykhaylova, O., 2009. Optimal Monetary Policy with Non-Zero Net Foreign Wealth. Working Paper, University of Richmond.

[25] Pappa, E., 2004. The Unbearable Tightness of Being in a Monetary Union: Fiscal Restrictions and Regional Stability. Mimeo, IGIER-Bocconi University.

[26] Schmitt-Grohé, S., Uribe, M., 2003. Closing Small Open Economy Models. Journal of International Economics 61, 163-185.

[27] Stockman, A., Tesar, L., 1995. Tastes and Technology in a Two-Country Model of the Business Cycle: Explaining International Comovements. The American Economic Review 85, 168-185.

[28] Tille, C., 2001. The Role of Consumption Substitutability in the International Transmission of Shocks. Journal of International Economics 53, 421-444. 


\section{A Data Sources and Description}

All data are taken from OECD Economic Outlook No. 77.

$P_{t} \quad$ Harmonized consumer price index

$Y_{t} \quad$ GDP at market prices, deflated by the HICP

$C_{t} \quad$ Private consumption, volume, deflated by the HICP

$I_{t} \quad$ Private fixed investment (excluding stockbuilding), volume, deflated by the HICP

$G_{t} \quad$ Government consumption (including wages), deflated by the HICP

$T_{t} \quad$ Government transfers (the sum of Subsidies, Social benefits paid by Government, and Other current transfers paid by government), deflated by the HICP

$B_{t} \quad$ Gross government debt, \% of GDP

$N_{t} \quad$ Average hours per employee times the Total employment

$W_{t} \quad$ Real total compensation per employee

$\pi_{t} \quad$ Inflation rate, calculated as $\log \left(\frac{P_{t}}{P_{t-1}}\right)$

$i_{t} \quad$ Short-term interest rate, approximated as $\log \left(1+i_{t}\right)$

Deficit Government net lending, \% of GDP 


\section{B Estimation}

\section{B.1 Productivity}

I assume that in the short run, nation-wide capital stock is fixed; this allows us to approximate total factor productivity (TFP) as $\ln Z_{t} \cong \ln Y_{t}-(1-\alpha) \ln N_{t}$. (Details on the variable definitions can be found in Appendix A.) I use 1980:12004:4 data on real output and employment to compute the TFP series for individual EMU members (where data are available) and for the monetary union as a whole, and then estimate VARs of the form

$$
\left[\begin{array}{l}
z_{t} \\
z_{t}^{*}
\end{array}\right]=\left[\begin{array}{ll}
A_{11} & A_{12} \\
A_{21} & A_{22}
\end{array}\right]\left[\begin{array}{l}
z_{t-1} \\
z_{t-1}^{*}
\end{array}\right]+\left[\begin{array}{l}
\varepsilon_{z, t} \\
\varepsilon_{z, t}^{*}
\end{array}\right],
$$

where $z_{t}$ is H-P filtered natural $\log$ of TFP for an individual country, and $z_{t}^{*}$ is the analogous value for the EMU area. Table 6 presents our estimation results.

Clearly, there is a lot of heterogeneity in our estimates; for the simulations, Portugal is used as the middle-of-the-road result (that is also statistically significant).

\section{B.2 Fiscal policy}

I compute the series of H-P filtered natural logs of real government purchases and transfers and estimate two autoregressions of the form

$$
\begin{aligned}
g_{t} & =\alpha_{0}+\alpha_{1} g_{t-1}+\varepsilon_{g, t} \\
t r_{t} & =\beta_{0}+\beta_{1} t r_{t-1}+\varepsilon_{t r, t}
\end{aligned}
$$

The results, using data for 1980:1-2004:4, are reported in Table 7:

In the simulations, I use Ireland's values, since they fall in the mid-range of the estimates. The value of $\alpha_{0}$ is chosen so that the steady state share of government purchases $\frac{G}{Y}$ is equal to 20 percent; $\beta_{0}$ is set to achieve 60 percent debt-to-GDP ratio in the steady state.

\section{B.3 Interest rate rule}

I assume that the monetary policy of the European Central Bank can be described by the Taylor rule of the form

$$
i_{t}=\alpha_{0}+\alpha_{1} i_{t-1}+\left(1-\alpha_{1}\right) \alpha_{2} \pi_{t}+\varepsilon_{i, t}
$$

The coefficients were estimated over two different periods: 1991:3-2004:4 (during the economic convergence process) and 1999:4-2004:4 (after the introduction of the Euro). The results of least squares estimations are presented in Table 8:

In the simulations, I use the average value for the weight on inflation: $\alpha_{2}=$ 1.4 . 


\begin{tabular}{|l|cccc|ccc|}
\hline Country & $A_{11}$ & $A_{12}$ & $A_{21}$ & $A_{22}$ & $\sigma^{2}\left(z_{t}\right)$ & $\sigma^{2}\left(z_{t}^{*}\right)$ & $\operatorname{Cov}\left(z_{t}, z_{t}^{*}\right)$ \\
\hline \hline Belgium & 0.69 & 0.02 & 0.11 & 0.64 & $4.8 \times 10^{-5}$ & $1.5 \times 10^{-5}$ & $1.6 \times 10^{-5}$ \\
& $(6.62)$ & $(0.10)$ & $(1.93)$ & $(7.21)$ & & & \\
\hline Finland & 0.82 & 0.16 & 0.05 & 0.66 & $1.1 \times 10^{-4}$ & $1.5 \times 10^{-5}$ & $1.4 \times 10^{-5}$ \\
& $(12.00)$ & $(0.74)$ & $(2.08)$ & $(8.39)$ & & & \\
\hline France & 0.31 & 0.49 & -0.22 & 0.99 & $2.1 \times 10^{-5}$ & $1.5 \times 10^{-5}$ & $1.5 \times 10^{-5}$ \\
& $(2.07)$ & $(2.99)$ & $(-1.72)$ & $(7.12)$ & & & \\
\hline Ireland & 0.52 & 0.42 & 0.01 & 0.76 & $1.9 \times 10^{-4}$ & $1.6 \times 10^{-5}$ & $1.6 \times 10^{-5}$ \\
& $(5.60)$ & $(1.79)$ & $(0.56)$ & $(11.18)$ & & & \\
\hline Italy & 0.36 & 0.47 & -0.05 & 0.83 & $5.2 \times 10^{-5}$ & $1.6 \times 10^{-5}$ & $2.1 \times 10^{-5}$ \\
& $(2.84)$ & $(2.63)$ & $(-0.66)$ & $(8.46)$ & & & \\
\hline Luxem. & 0.89 & 0.01 & 0.03 & 0.73 & $7.0 \times 10^{-5}$ & $1.5 \times 10^{-5}$ & $1.2 \times 10^{-5}$ \\
& $(16.28)$ & $(0.01)$ & $(1.08)$ & $(10.33)$ & & & \\
\hline Nether. & 0.51 & 0.14 & 0.02 & 0.76 & $6.0 \times 10^{-5}$ & $1.6 \times 10^{-5}$ & $1.1 \times 10^{-5}$ \\
& $(5.45)$ & $(1.07)$ & $(0.39)$ & $(11.09)$ & & & \\
\hline Portugal & 0.83 & 0.39 & 0.03 & 0.72 & $1.3 \times 10^{-4}$ & $1.5 \times 10^{-5}$ & $5.6 \times 10^{-5}$ \\
& $(16.00)$ & $(2.06)$ & $(1.78)$ & $(11.07)$ & & & \\
\hline Spain & 0.37 & 0.07 & 0.00 & 0.77 & $4.4 \times 10^{-5}$ & $1.6 \times 10^{-5}$ & $0.8 \times 10^{-5}$ \\
& $(3.77)$ & $(0.68)$ & $(0.03)$ & $(12.07)$ & & & \\
\hline
\end{tabular}

Table 6: Estimates of the productivity processes (t-stats in parentheses).

\begin{tabular}{|l|lll|}
\hline Country & $\alpha_{1}$ & $\beta_{1}$ & $\operatorname{Var}\left(g_{t}\right)$ \\
\hline \hline Finland & 0.80 & 0.92 & $1.7 \times 10^{-4}$ \\
& $(12.92)$ & $(26.06)$ & \\
\hline France & 0.87 & 0.85 & $2.0 \times 10^{-5}$ \\
& $(17.10)$ & $(15.93)$ & \\
\hline Ireland & 0.92 & 0.87 & $8.9 \times 10^{-5}$ \\
& $(21.87)$ & $(17.71)$ & \\
\hline Nether. & 0.69 & 0.94 & $9.7 \times 10^{-5}$ \\
& $(9.02)$ & $(27.30)$ & \\
\hline
\end{tabular}

Table 7: Estimates of the government policy processes ( $t$-stats in parentheses).

\begin{tabular}{|c|cccc|}
\hline Period & $\alpha_{0}$ & $\alpha_{1}$ & $\alpha_{2}$ & $\sigma_{\varepsilon}$ \\
\hline \hline $1991: 3-2004: 4$ & -0.00 & 0.95 & 1.27 & $1.06 \times 10^{-3}$ \\
& $(-0.27)$ & $(32.01)$ & $(1.04)$ & \\
\hline $1999: 1-2004: 4$ & -0.00 & 0.94 & 1.73 & $1.01 \times 10^{-3}$ \\
& $(-0.28)$ & $(11.41)$ & $(1.4)$ & \\
\hline
\end{tabular}

Table 8: Estimates of the Taylor Rule (t-stats in parentheses). 